
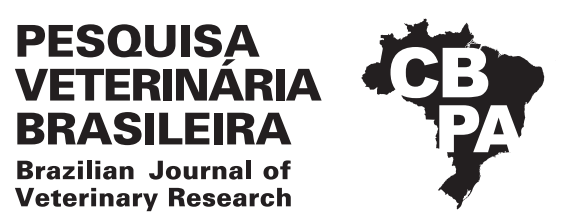

Pesq. Vet. Bras. 39(1):52-60, janeiro 2019 DOI: 10.1590/1678-5150-PVB-5843

ISSN 0100-736X (Print)

ISSN 1678-5150 (Online)

\title{
Use of different fixation times and application of two immunohistochemical methods for detection of KIT and Ki67 proteins in canine cutaneous mast cell tumors ${ }^{1}$
}

\author{
Alex dos Santos ${ }^{2}$, Harlan H.L. Nascimento ${ }^{2}$, Mariana M. Flores ${ }^{3}$ \\ and Glaucia D. Kommers ${ }^{3 *}$
}

\begin{abstract}
Santos A., Nascimento H.H.L., Flores M.M. \& Kommers G.D. 2019. Use of different fixation times and application of two immunohistochemical methods for detection of KIT and Ki67 proteins in canine cutaneous mast cell tumors. Pesquisa Veterinária Brasileira 39(1):52-60. Laboratório de Patologia Veterinária, Departamento de Patologia, Universidade Federal de Santa Maria, Camobi, Santa Maria, RS 97105-900, Brazil. E-mail: glaukommers@yahoo.com

Due to the high prevalence of mast cell tumors (MCTs) in the diagnostic routine, several factors, especially prognostic, have been sought to determine the biological behavior of these neoplasms. Immunohistochemistry (IHC) is one of the main tools utilized to biologically differentiate more aggressive tumors from less aggressive ones. However, some immunostainings are influenced by formalin fixation, interfering with the results. This is both a retrospective and prospective study of MCTs diagnosed in laboratory routine. A total of 25 samples, without knowledge about fixation time, were analyzed in the retrospective study, whereas 12 samples, with known fixation times, were assessed in the prospective study. Two histologic grading systems (Patnaik and Kiupel), special staining of toluidine blue, and IHC for KIT and Ki67 proteins were applied in both studies. Additionally, two amplification systems (biotinylated and non-biotinylated) for Ki67 protein and counting of the argyrophilic nucleolar organizing regions (AgNOR method) were tested in the prospective study. In the retrospective study, greater agreement between the evaluating pathologists was observed when the Kiupel system was used. IHC staining for KIT protein was effective in both studies, regardless of fixation time. IHC staining for Ki67 protein was highly sensitive to formaldehyde, and staining failure was observed in $56 \%$ of the cases in the retrospective study. In the prospective study, samples fixed for longer than 24 hours showed a reduction in the number of stained cells (altering the determination of the cell growth fraction) or showed absence of IHC staining in both amplification systems. The use of the AgNOR method to evaluate the rate of cell proliferation may be an alternative when the fixation time of the neoplasm is unknown or longer than 24 hours.
\end{abstract}

INDEX TERMS: Immunohistochemistry, KIT protein, Ki67 protein, cutaneous mast cell tumors, histologic grading, dogs.

\footnotetext{
${ }^{1}$ Received on August 10, 2018.

Accepted for publication on September 29, 2018.

Part of the Master's Thesis of the first author.

${ }^{2}$ Postgraduate Program in Veterinary Medicine, área de concentração em Patologia e Patologia Clínica Veterinária, Centro de Ciências Rurais (CCR), Universidade Federal de Santa Maria (UFSM), Av. Roraima 1000, Camobi, Santa Maria, RS 97105-900, Brazil.

${ }^{3}$ Laboratório de Patologia Veterinária, Departamento de Patologia, Centro de Ciências da Saúde, Universidade Federal de Santa Maria (UFSM), Santa Maria, RS. *Corresponding author: glaukommers@yahoo.com
}

RESUMO.- [Utilização de diferentes tempos de fixação e métodos imuno-histoquímicos na detecção das proteínas KIT e Ki67 em mastocitomas cutâneos caninos.] Devido a alta prevalência dos mastocitomas cutâneos caninos (MCCs) na rotina diagnóstica, vários fatores, especialmente fatores prognósticos, têm sido buscados para auxiliar na determinação do comportamento biológico desse neoplasma. A imuno-histoquímica é uma das principais ferramentas 
empregadas para diferenciar tumores biologicamente mais agressivos de tumores menos agressivos. Entretanto, algumas imunomarcações sofrem influência pela fixação em formol, interferindo nos resultados. Este estudo compreendeu avaliar através de uma etapa retrospectiva e uma etapa prospectiva casos de MCCs diagnosticados na rotina laboratorial. Um total de 25 amostras, sem conhecimento do tempo de fixação, foi analisado no estudo retrospectivo e 12 amostras, com tempos de fixação conhecidos, no estudo prospectivo. Foram aplicados nos dois estudos, dois sistemas de graduação histológica (Patnaik e Kiupel), a coloração especial de azul de toluidina e a imuno-histoquímica para as proteínas KIT e Ki67. Adicionalmente, no estudo prospectivo, foram testados dois sistemas de amplificação (biotinilado e não biotinilado) para a proteína Ki67 e a técnica de AgNOR (contagem das regiões organizadoras nucleolares argirofílicas). Na etapa retrospectiva, observou-se uma maior concordância entre os patologistas avaliadores quando o sistema Kiupel foi utilizado. A imunomarcação para KIT se manteve eficaz em ambos os estudos, independentemente do tempo de fixação. A imunomarcação para o Ki67 mostrou-se altamente sensível ao tempo de fixação em formol, sendo observada falha na imunomarcação em $56 \%$ dos casos do estudo retrospectivo. No estudo prospectivo, constatou-se que amostras fixadas por mais de 24 horas em formol apresentaram redução na quantidade de células imunomarcadas (alterando a determinação da fração de crescimento celular) ou apresentaram ausência de imunomarcação em ambos os sistemas de amplificação. A utilização do método AgNOR, para avaliar a taxa de proliferação celular, pode ser uma alternativa quando o tempo de fixação do neoplasma for desconhecido ou superior a 24 horas.

TERMOS DE INDEXAÇÃO: Imuno-histoquímica, proteína KIT, proteína Ki67, mastocitoma cutâneo, graduação histológica, cães.

\section{INTRODUCTION}

Cutaneous mast cell tumors (MCTs) are among the most prevalent malignant neoplasms affecting the skin of dogs (Patnaik et al. 1984, Goldschmidt \& Hendrick 2002, Romansik et al. 2007, Kiupel 2017). Despite the differences in epidemiology, it is worth noting that the biological behavior of MCTs is highly variable (Webster et al. 2007, Gross et al. 2009).

Histologic grading has been used in an attempt to predict the biological behavior of MCTs for decades (Bostock 1973, Patnaik et al. 1984, Kiupel et al. 2011). Patnaik et al. (1984) suggested the grading classification most commonly used and applied in veterinary pathology laboratories until recently. According to this system, MCTs are divided into three grades: grade I (well-differentiated), grade II (intermediately differentiated), and grade III (poorly differentiated). Although widely used, this method is considered as of difficult application by some authors (Northrup et al. 2005a, 2005b), mainly because it includes a large number of subjective histologic criteria.

Owing to criticisms of the Patnaik system (PS), a new grading method was proposed in 2011 (Kiupel et al. 2011). This new method is considered easier to apply due to: (1) use of fewer histologic criteria; (2) lower subjectivity of the criteria used; (3) classification of tumors into only two groups: high and low grade. Despite the advantages of this method, ancillary techniques must be used together with histologic grading in an attempt to predict the biological behavior of MCTs (Kiupel et al. 2011).

In parallel, immunohistochemistry (IHC) and polymerase chain reaction (PCR) have been used to assist with determining the prognosis of MCTs (Kiupel et al. 2004, Webster et al. 2006, 2007, Kandefer-Gola et al. 2015). Using IHC, especially with antibodies that detect KIT (tyrosine kinase membrane receptor) and Ki67 (marker of cell proliferation) proteins, it is possible to identify the tumors that are most likely to be biologically more aggressive (Webster et al. 2007, Strefezzi et al. 2010, Flores et al. 2016, Sledge et al. 2016). PCR has been used in the search for mutations in the c-KIT gene, which present prognostic value and influence the therapeutic approach to each patient (Webster et al. 2006, Kiupel 2017). In addition to histologic grading, with application of IHC as well as PCR, it is possible to obtain a more reliable assessment of the biological behavior of MCTs, which directly influences the choice of therapy (Kiupel et al. 2004, Webster et al. 2006, Sledge et al. 2016, Kiupel 2017).

Despite the existence and relevance of the complementary prognostic tools previously discussed, the influence of tissue fixation time on formaldehyde is an important concern, and may hinder the prognostic evaluation of MCTs in a diagnostic routine. The most widely used tissue fixative in histopathology is formaldehyde, which is usually used as $10 \%$ neutral buffered formalin. This cross-linking fixative preserves the architecture of tissue, especially the peptides and cellular organelles, avoiding its degradation. In contrast, prolonged fixation causes changes in the conformation of macromolecules, which may hinder or even prevent the recognition of proteins (antigens). Antigen retrieval (enzymatic or heat-induced), a method applied for IHC, may partially or fully reverse the deleterious effects of prolonged formalin fixation (Ramos-Vara \& Miller 2014). Moreover, the use of different amplification systems in IHC can lead to an optimized immunostaining method for certain antigens (Galiza et al. 2014).

In this context, this study aimed mainly at (1) assessing the efficacy of immunostaining for KIT and Ki67 proteins in MCTs classified according to the Patnaik and Kiupel systems and relating it to formalin fixation time; (2) testing two different IHC protocols (with variations in the amplification system) in an attempt to determine possible differences for each of the two antibodies used. The purpose of this study is to generate knowledge about the technical aspects of IHC for KIT and Ki67 proteins, providing subsidies for the application of this technique in diagnostic routine, particularly in Brazilian laboratories, which present difficulties regarding variation in the fixation times of the MCT samples received.

\section{MATERIALS AND METHODS}

\section{Retrospective study}

Histologic grading and histochemical evaluation. The retrospective study sample was composed of 25 cases of cutaneous mast cell tumors (MCTs) diagnosed in dogs at the Veterinary Pathology Laboratory of the Federal University of Santa Maria from January 2011 to January 2016. In addition to the diagnosis, the inclusion criteria comprised availability of paraffin blocks for each selected case. Two slides of each case ( $3 \mu \mathrm{m}$-thick histologic section) were prepared: one slide was stained using the hematoxylin and eosin (HE) technique and the other was stained using the toluidine blue (TB) method, for detection of metachromatic granules in the cytoplasm. Measurement 
classified cytoplasmic granules into accentuated, moderate, and discrete. Subsequently, the HE slides were submitted to the Patnaik (grades I, II, and III; Patnaik et al. 1984) and Kiupel (high and low grade; Kiupel et al. 2011) histologic grading methods independently by three pathologists $(A S, M M F$, and $G D K$ ). Aiming to reduce analysis subjectivity, the evaluators received a table with all the histologic criteria to be assessed for each system according to the respective literature. Subsequently, the cases with divergence were discussed, and a consensus table was compiled with a single grading of each method, Patnaik (PS) and Kiupel (KS) systems, for each neoplasm.

Immunohistochemistry (IHC). IHC was performed on the 25 MCTs using the primary rabbit polyclonal anti-human KIT antibody (CD117, Dako Cytomation, A4502) and the primary mouse monoclonal anti-human Ki67 antibody (clone MIB-1, Dako Cytomation, M7240). The methods used for KIT and Ki67 proteins were adapted from Kiupel et al. (2004) and Webster et al. (2007), respectively. Tissue sections were submitted to the IHC protocols described in Table 1. In all protocols, endogenous peroxidase activity was blocked with $3 \%$ hydrogen peroxide $2 x$ for $10 \mathrm{~min}$, and blocking of non-specific reactions was performed with protein blocker (EP-12-20532, EasyPath) at room temperature $\left(25^{\circ} \mathrm{C}\right)$ for $10 \mathrm{~min}$. After quick washing with distilled water, the one-stage non-biotinylated amplification system (HRP-polymer, EasyLinkOne, EP-12-20502, EasyPath) was incubated at room temperature for 20 minutes. Counterstain was performed with Harris hematoxylin. Cases of MCT previously submitted to IHC for KIT protein by Flores et al. (2016) were used as positive controls. A section of the analyzed tissue incubated only with the antibody diluent (phosphate buffered saline with Tween ${ }^{\circledR}$ 20-Sigma - PBST) was used as negative control of each case.

Classification of KIT antigen was performed as in Kiupel et al. (2004), according to localization of immunostaining in the tumor mast cells, with tumors divided into three patterns: pattern I, membrane-associated, with little to no cytoplasmic staining; pattern II, intense cytoplasmic staining with focal or stippled distribution; pattern III, diffuse cytoplasmic staining of neoplastic mast cells. Intensity, number, and distribution of the immunostained cells were also analyzed for this immunomarker. Classification of Ki67 protein was performed according to Webster et al. (2007), that is, after identification of the grid area with the largest number of immunostained neoplastic cells (nuclear dotted black), the number of immunopositive cells present was counted over five distinct high-power fields (HPF; 40x) by two examiners and subsequently averaged to obtain the growth fraction, with MCTs divided into two groups: low (LGF; $<23$ ) and high (HGF; $\geq 23$ ) growth fraction.

\section{Prospective study}

Histologic grading and histochemical evaluation. The retrospective study sample was consisted of 12 cases of cutaneous mast cell tumors (MCTs) diagnosed in dogs at the LPV-UFSM from August 2016 to May 2017. The neoplasms were separately fixed (in 10\% neutral formalin) at the following fixation times: 24, 48, 72, and 96 hours. All samples were routinely processed for histopathology and embedded in paraffin. Only the samples that underwent $24 \mathrm{~h}$ fixation were sectioned at $3 \mu \mathrm{m}$ and stained according to the hematoxylin and eosin (HE), toluidine blue (TB), and count of the argyrophilic nucleolar organizing regions (AgNOR) techniques. Subsequently, histologic grading was applied according to PS and KS, as previously described in the retrospective study.

For AgNOR staining, the $3 \mu \mathrm{m}$-thick histologic sections were deparaffinized and hydrated in deionized water. They were then stained in a solution containing a mixture of $2 \%$ gelatin and $1 \%$ formic acid in deionized water and $50 \%$ silver nitrate solution at a ratio of $1: 2$, respectively. The slides were immersed in this solution at room temperature for 30 minutes. After that, they were washed with deionized water for $1 \mathrm{~min}$, dehydrated, clarified, and assembled with synthetic mounting medium (Entellan new, Merck) (Bostock et al. 1989). The AgNORs were manually counted according to Bostock et al. (1989); to define the frequency of AgNOR, the black dots were counted within the nuclei in 100 randomly selected neoplastic mast cells throughout the tumor at $1000 \mathrm{x}$ magnification. Frequency was determined by dividing the AgNOR number by 100 .

Immunohistochemistry (IHC). Two amplification systems were used: non-biotinylated (HRP-polymer; EasyLinkONE) and biotinylated (LSAB+System-HRP [Dako]). The 12 samples were tested with the same antibodies used in the retrospective study (KIT and Ki67) at 24, 48, 72, and 96h fixation times (Table 1). For the biotinylated system, after incubation with the primary antibody, the biotinylated secondary antibody (stage 1) was incubated at room temperature for 30 minutes. After washing with PBST ( $2 x$ for $5 \mathrm{~min}$ ), stage 2 consisted of incubation at room temperature for $30 \mathrm{~min}$ with the streptavidin-biotin-peroxidase complex. Interpretation of immunostaining for the primary antibodies followed the same criteria previously described in the retrospective study.

Table 1. Description of protocols performed to optimize immunohistochemistry with anti-KIT and anti-Ki67 antibodies

\begin{tabular}{|c|c|c|c|c|c|c|}
\hline & $\mathrm{Ab}^{\mathrm{c}}$ & Antigen retrieval ${ }^{\mathrm{h}}$ & Dilution $^{\mathrm{d}}$ & $\begin{array}{l}\text { Incubation (time/ } \\
\text { temperature) }\end{array}$ & $\begin{array}{c}\text { Secondary antibody/ } \\
\text { amplification }\end{array}$ & Substrate-Chromogen \\
\hline \multirow[t]{2}{*}{$\mathrm{R}^{\mathrm{a}}$} & Anti-KIT & $\begin{array}{l}\text { Tris-EDTA } \\
(\mathrm{pH} \mathrm{9.0)}\end{array}$ & $1: 200$ & $1 \mathrm{~h} / 37 \mathrm{C}^{\circ}$ & Non-biotinylated ${ }^{\mathrm{e}}$ & $\mathrm{DAB}^{\mathrm{g} *}$ \\
\hline & Anti-Ki67 & $\begin{array}{l}\text { Citrate } \\
(\mathrm{pH} 6.0)\end{array}$ & $1: 50$ & $1 \mathrm{~h} / 37 \mathrm{C}^{\circ}$ & Non-biotinylated & DAB* \\
\hline \multirow[t]{2}{*}{$\mathrm{P}^{\mathrm{b}}$} & Anti-KIT & $\begin{array}{l}\text { Tris-EDTA } \\
(\mathrm{pH} \mathrm{9.0)}\end{array}$ & $1: 200$ & $1 \mathrm{~h} / 37 \mathrm{C}^{\circ}$ & Non-biotinylated & DAB* \\
\hline & Anti-Ki67 & $\begin{array}{l}\text { Citrate } \\
(\mathrm{pH} \mathrm{6.0)}\end{array}$ & $1: 50$ & $1 \mathrm{~h} / 37 \mathrm{C}^{\circ}$ & $\begin{array}{c}\text { Biotinylated }^{\mathrm{f}} \\
\text { Non-biotinylated }\end{array}$ & DAB* \\
\hline
\end{tabular}




\section{RESULTS}

\section{Retrospective study}

Histologic grading and histochemical evaluation. Interrater agreement between the three evaluators was $88 \%$ $(22 / 25)$ and 96\% (24/25) for the Patnaik (PS) and Kiupel (KS) systems, respectively. Mitotic count in one case was a divergent aspect in the SK. Application of grading (consensus) according to the PS showed that $96 \%(24 / 25)$ of the neoplasms were grade II and $4 \%(1 / 25)$ of them were grade III.

Application of grading according to the KS resulted in $84 \%(21 / 25)$ of mast cell tumors (MCTs) with low grade (Fig.1A) and 16\% (4/25) with high grade (Fig.1B). Of the $24 / 25$ MCTs classified as grade II by the PS, 21/24 were low grade and 3/24 were high grade when the SK was applied. The only grade III (PS) case was classified as low grade (KS).

In the toluidine blue (TB) technique, the MCTs metachromatically stained (in purple) the cytoplasmic granules markedly in $52 \%(13 / 25)$, moderately in $24 \%(6 / 25)$, slightly in $20 \%(5 / 25)$, and no staining was observed in $4 \%$ $(1 / 25)$, which presented grade III by the PS and high grade according to the KS.

Immunohistochemistry (IHC). Positive immunostaining was observed in all MCTs tested for KIT antigen and in 11/25 $(44 \%)$ of the cases tested for Ki67 protein.

For KIT antigen, $64 \%(16 / 25)$ of the neoplasms presented immunostaining pattern II (cytoplasm; Fig.2A) and 36\% (9/25) showed pattern I (membrane; Fig.2B). Regarding intensity, $56 \%(14 / 25)$ of the cases were markedly, $28 \%(7 / 25)$ were moderately, and $16 \%(4 / 25)$ were slightly stained. As for the number and distribution of immunostained cells, 52\% $(13 / 25)$ of the cases presented a large number of cells evenly distributed in the analyzed section and $48 \%(12 / 25)$ of them showed a few randomly distributed cells. Of the 16 MCTs that presented pattern II, 15 were grade II and one was grade III by the PS, whereas 14 were low grade and two were high grade according to the KS. Of the nine neoplasms that showed pattern I, all were grade II according to the PS, whereas seven were low grade and two were high grade by the KS.

All of the MCTs immunostained for Ki67 antigen (11/25; $44 \%$ ) presented low growth fraction (LGF). No immunostaining was observed in 14/25 (56\%) of the neoplasms.

\section{Prospective study}

Histologic grading and histochemical evaluation. According to the PS, 11/12 (92\%) of the MCTs were grade II and 1/12 (8\%) was grade III. Application of the KS showed that $8 / 12(67 \%)$ of the neoplasms were low grade and $4 / 12$ (33\%) were high grade. In the TB technique, $6 / 12$ of the MCTs stained the granules markedly, 4/12 moderately, and 2/12 slightly. In AgNOR, counting ranged from 1.22 to 1.97 (mean of 1.44) for grade II neoplasms and 2.89 for grade III neoplasms.

Immunohistochemistry (IHC). Positive immunostaining was observed in all MCTs at all formalin fixation times tested for KIT protein. Under microscopic examination, 59\% (seven) of the cases presented pattern II (cytoplasm) and $41 \%$ (five) showed immunostaining pattern I (membrane). Of the seven neoplasms that presented pattern II, six were grade II and one was grade III by the PS, whereas four were high grade and three were low grade using the KS. Of the five MCTs that showed pattern I, all were grade II and low grade after application of the PS and KS, respectively. No difference between the two amplification systems (biotinylated and non-biotinylated) was observed regarding intensity of the immunostained cells. With respect to the number and distribution of immunostained cells, $75 \%$ (nine) of the neoplasms presented a large number cells evenly distributed in the analyzed section and 25\% (three) of them showed few randomly distributed cells.

With respect to Ki67 antigen, at formalin fixation for 24 hours, high growth fraction (HGF) was observed in four and three MCTs in the non-biotinylated and biotinylated amplification systems, respectively (Figs.2C,D), whereas

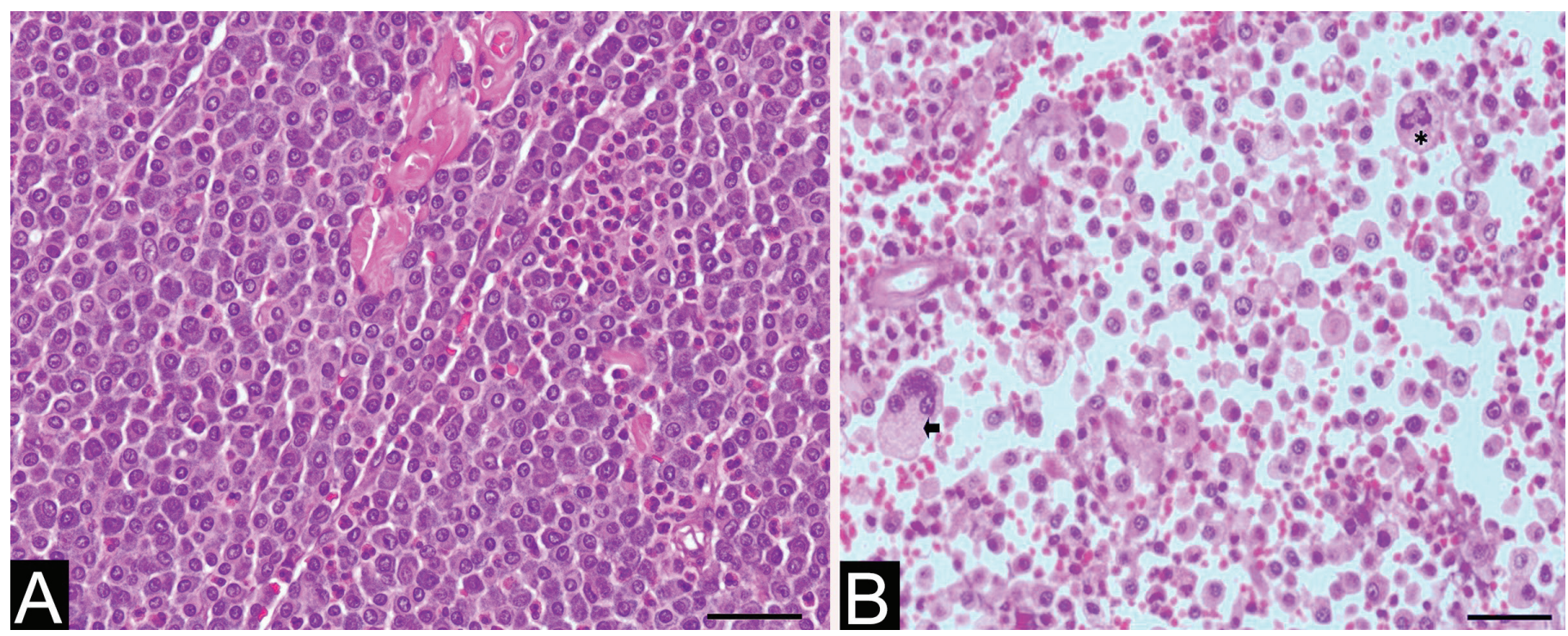

Fig.1. Histologic characteristics of cutaneous mast cell tumors in dogs. (A) Dog, skin. Low grade mast cell tumor according to the Kiupel system. HE, obj.40x. (B) Dog, skin. High grade mast cell tumor according to the Kiupel system. A pronounced pleomorphism is observed, with multinucleated cell (arrow) and mitotic figure (asterisk). HE, obj.40x. 


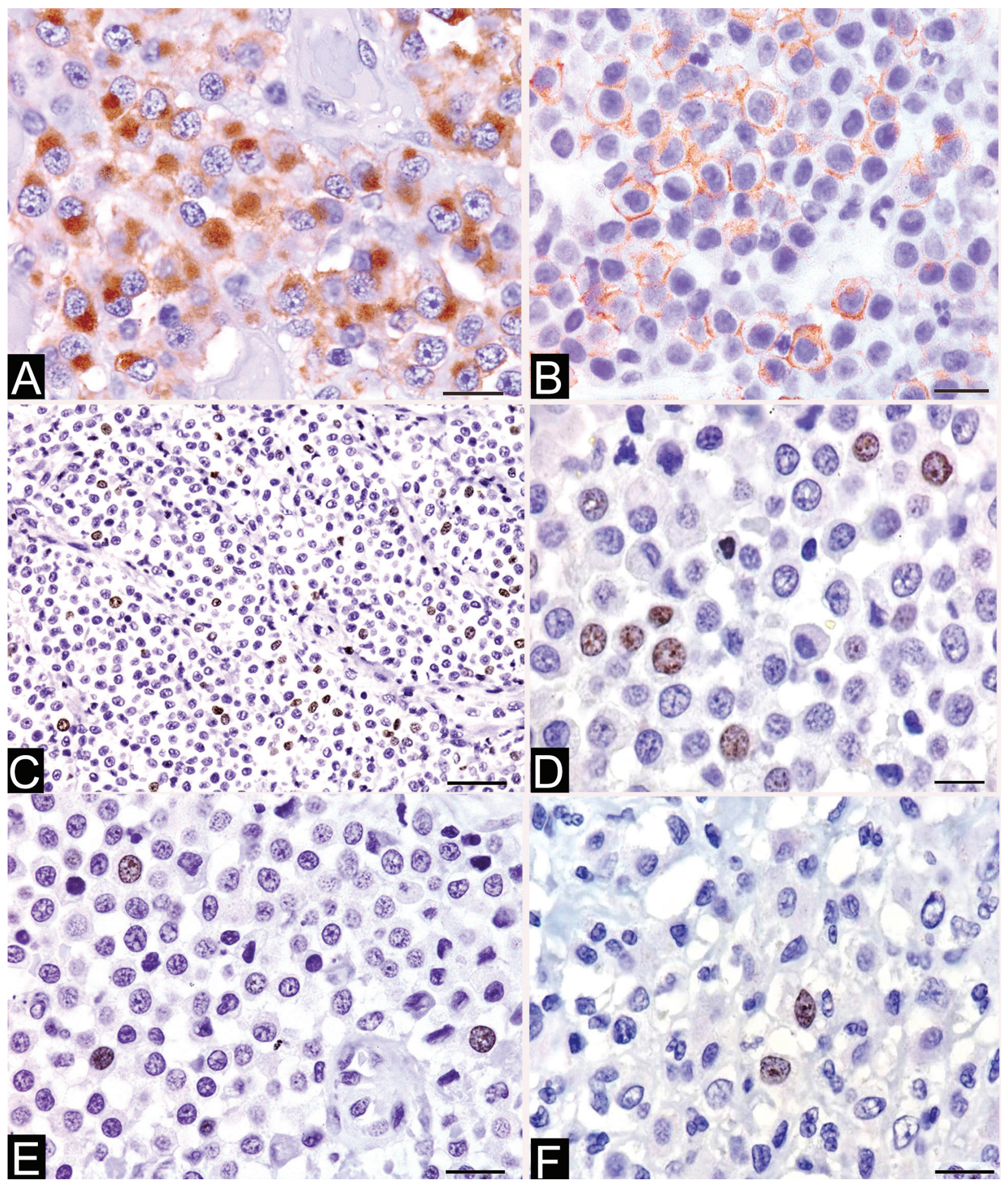

Fig.2. Immunohistochemical characteristics of cutaneous mast cell tumors in dogs. (A) Dog, skin. Mast cells showing intense cytoplasm immunostaining (pattern II) for KIT protein. Non-biotinylated method (HRP-polymer), obj.100x. (B) Dog, skin. Mast cells exhibiting cell membrane immunostaining (pattern I) for KIT protein. Non-biotinylated method (HRP-polymer), obj.100x. (C) Dog, skin. Mast cells presenting nuclear immunostaining for Ki67 protein. High cell growth fraction. $24 \mathrm{~h}$ formalin fixation. Non-biotinylated method (HRP-polymer), obj.40x. (D) Neoplastic mast cells presenting nuclear immunostaining for Ki67 protein. High cell growth fraction. $24 \mathrm{~h}$ formalin fixation. Biotinylated method (streptavidin-biotin-peroxidase complex), obj.100x. (E) Dog, skin. Neoplastic mast cells presenting nuclear immunostaining for Ki67 protein. Low cell growth fraction. 24h formalin fixation. Biotinylated method (HRP-polymer), obj.100x. (F) Dog, skin. Neoplastic mast cells presenting nuclear immunostaining for Ki67 protein. Low cell growth fraction. $24 \mathrm{~h}$ formalin fixation. Biotinylated method (streptavidin-biotin-peroxidase complex), obj.100x. 
LGF was found in eight and nine neoplasms in the first and latter systems, respectively (Figs.2E,F). Table 2 presents the growth fraction results based on Ki67 protein detection at the four formalin fixation times comparing the two amplification systems. Figure 3 depicts the Ki67 absolute values at the four fixation times comparing both systems.

In the non-biotinylated amplification system, 7/12 of the MCTs maintained the growth fraction at the four fixation times tested; in 3/12 of them, a change was observed in growth fraction detection, which shifted from high to low after 24 hours of fixation; no immunostaining was verified in $2 / 12$ and $1 / 12$ of the neoplasms after 48 and 72 hours of fixation, respectively.

In the non-biotinylated system, $5 / 12$ of the MCTs maintained the growth fraction at the four fixation times; in 2/12 and 1/12 of them, a change was observed in growth fraction detection, which shifted from high to low after 24 and 72 hours of fixation, respectively; no immunostaining was verified in $1 / 12$ and $3 / 12$ of the neoplasms after 48 and 72 hours of fixation, respectively.

\section{DISCUSSION}

Concerning the histologic grading of the 25 mast cell tumors (MCTs) analyzed in the retrospective study, greater interrater agreement was observed with application of the Kiupel System (KS) (96\%) compared with that of the Patnaik System (PS) $(88 \%)$. These results are similar to those reported in the study where the KS was proposed, in which concordance between pathologists in the PS was 75\% for grade III and approximately $60 \%$ for grades I and II; in the KS, regardless of the grade assigned, agreement was higher than 96\% (Kiupel et al. 2011). Reduction in the variations between evaluators in the KS has been attributed to classification in only two grades, as it is based on more objective and simplified histologic criteria (Kiupel et al. 2011). The importance of establishing a high grade for MCTs lies in the fact that these neoplasms were

Table 2. Results of the cell growth fraction based on detection of Ki67 protein using the non-biotinylated and biotinylated amplification systems according to formalin fixation time in the prospective study

\begin{tabular}{|c|c|c|c|c|c|c|c|c|}
\hline \multirow{2}{*}{ Case no. } & \multicolumn{4}{|c|}{ Non-biotinylated } & \multicolumn{4}{|c|}{ Biotinylated } \\
\hline & $24 \mathrm{~h}$ & $48 \mathrm{~h}$ & $72 \mathrm{~h}$ & $96 \mathrm{~h}$ & $24 \mathrm{~h}$ & $48 \mathrm{~h}$ & $72 \mathrm{~h}$ & $96 \mathrm{~h}$ \\
\hline 1 & $\downarrow$ & $\downarrow$ & $\downarrow$ & $\downarrow$ & $\downarrow$ & $\downarrow$ & - & - \\
\hline 2 & $\uparrow$ & $\downarrow$ & - & - & $\uparrow$ & $\uparrow$ & $\downarrow$ & $\downarrow$ \\
\hline 3 & $\uparrow$ & $\downarrow$ & $\downarrow$ & $\downarrow$ & $\uparrow$ & $\downarrow$ & $\downarrow$ & $\downarrow$ \\
\hline 4 & $\downarrow$ & $\downarrow$ & $\bullet$ & - & $\downarrow$ & $\downarrow$ & $\downarrow$ & $\downarrow$ \\
\hline 5 & $\downarrow$ & $\downarrow$ & $\downarrow$ & $\downarrow$ & $\downarrow$ & $\downarrow$ & $\downarrow$ & $\downarrow$ \\
\hline 6 & $\downarrow$ & $\downarrow$ & $\downarrow$ & $\bullet$ & $\downarrow$ & $\downarrow$ & $\downarrow$ & $\bullet$ \\
\hline 7 & $\downarrow$ & $\downarrow$ & $\downarrow$ & $\downarrow$ & $\downarrow$ & $\downarrow$ & $\downarrow$ & $\downarrow$ \\
\hline 8 & $\uparrow$ & $\uparrow$ & $\uparrow$ & $\uparrow$ & $\uparrow$ & $\downarrow$ & $\downarrow$ & $\downarrow$ \\
\hline 9 & $\downarrow$ & $\downarrow$ & $\downarrow$ & $\downarrow$ & $\downarrow$ & $\downarrow$ & $\downarrow$ & $\downarrow$ \\
\hline 10 & $\uparrow$ & $\downarrow$ & $\downarrow$ & $\downarrow$ & $\downarrow$ & $\downarrow$ & $\downarrow$ & $\bullet$ \\
\hline 11 & $\downarrow$ & $\downarrow$ & $\downarrow$ & $\downarrow$ & $\downarrow$ & $\downarrow$ & $\downarrow$ & $\bullet$ \\
\hline 12 & $\downarrow$ & $\downarrow$ & $\downarrow$ & $\downarrow$ & $\downarrow$ & $\downarrow$ & $\downarrow$ & $\downarrow$ \\
\hline
\end{tabular}

$\downarrow$ Low cell growth fraction, $\uparrow$ high cell growth fraction, $\bullet$ without immunostaining. more rapidly associated with animal metastasis or relapse, as well as with lower survival (Kiupel et al. 2011).

Counting of the argyrophilic nucleolar organizing regions (AgNOR) is a tool used to assist with assessing cell proliferation. This histochemical method quantitatively evaluates the rate at which tumor cells are proliferating (growth rate) (Derenzini 2000). The AgNOR values found in this study corroborate the specific scientific literature, which reports average AgNOR values for grade II MCTs from 1.28 to 3.96 (Bostock et al. 1989, Rech et al. 2004). The larger the number of AgNORs observed in the nucleus of the neoplastic cells, the greater the proliferative activity of the tumor (Derenzini 2000). Bostock et al. (1989) observed that the survival time for dogs with AgNOR $<4$ is almost three fold that of dogs with AgNOR >4. Ozaki et al. (2007), in addition to evaluating cell proliferation markers (Ki67, PCNA, and AgNOR), also assessed surgical resection, intratumoral vessel density, nuclear morphometry, and tumor depth and location.

Currently, two immunomarkers have been used to complement histologic grading in determination of biological behavior of MCTs, namely, KIT (tyrosine kinase membrane receptor) (Kiupel et al. 2004, Kiupel 2017) and Ki67 (marker of cell proliferation) (Webster et al. 2007). Sledge et al. (2016) created a flowchart on the prognostic evolution of MCTs based on the assessment of some criteria, surgical margin, histologic grading, clinical staging, and depending on the results, application of immunohistochemistry (IHC) (KIT and Ki67) and polymerase chain reaction (PCR) (mutations in exon 11), to determine the treatment to be used in each case. In this study, we sought to standardize and optimize the IHC technique for KIT and Ki67 proteins in samples received for routine diagnosis, without knowledge about formalin fixation time (retrospective study), because this is our current laboratory reality; subsequently, we worked with known fixation times (prospective study).

Immunostaining for KIT protein was not sensitive to prolonged fixation in formalin, with immunoreactivity observed in all cases, both in the retrospective and prospective studies. However, changes in the intensity, number, and distribution of immunostained cells were observed, which were heterogeneous but did not prevent identification of neoplastic cells as mast cells or determination of the immunostaining pattern. A factor considered important for the development of heterogeneous immunostaining for a given antigen is that formalin penetration is not homogeneous in relation to tissue fixation, occurring in centripetally (Ramos-Vara \& Miller 2014).

Joint analysis of the retrospective and prospective studies showed immunostaining pattern II (cytoplasm) in $62 \%$ and pattern I (membrane) in 38\% of the MCTs. Pattern III immunostaining was not observed in the present study. The vast majority of low grade neoplasms presented immunostaining pattern II, corroborating with the literature (Webster et al. 2007, Fonseca-Alves et al. 2015, Flores et al. 2016, Sledge et al. 2016). This information is important considering that it has been observed that MCTs that lose membrane expression and acquire cytoplasmic expression for KIT antigen, present a more aggressive biological behavior (Kiupel et al. 2004). Similarly, Webster et al. (2006) reported positive correlation between loss of membrane staining and presence of mutations in exon 11 , suggesting that mutations may play a role in KIT protein localization. Mutations in the juxtamembrane domain of the 
LGF Ki67 Non-biotinylated I

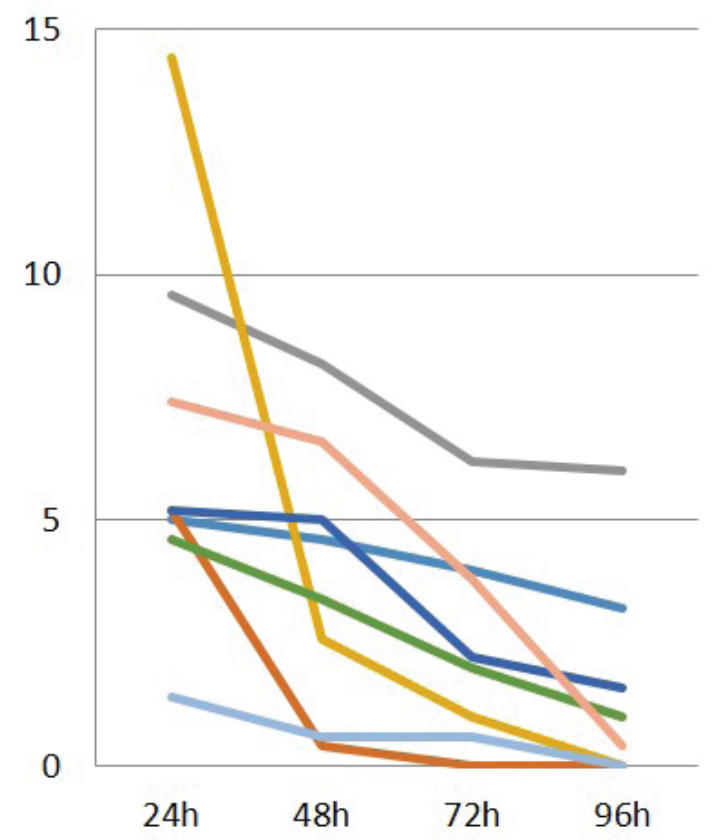

LGF Ki67 Biotinylated III

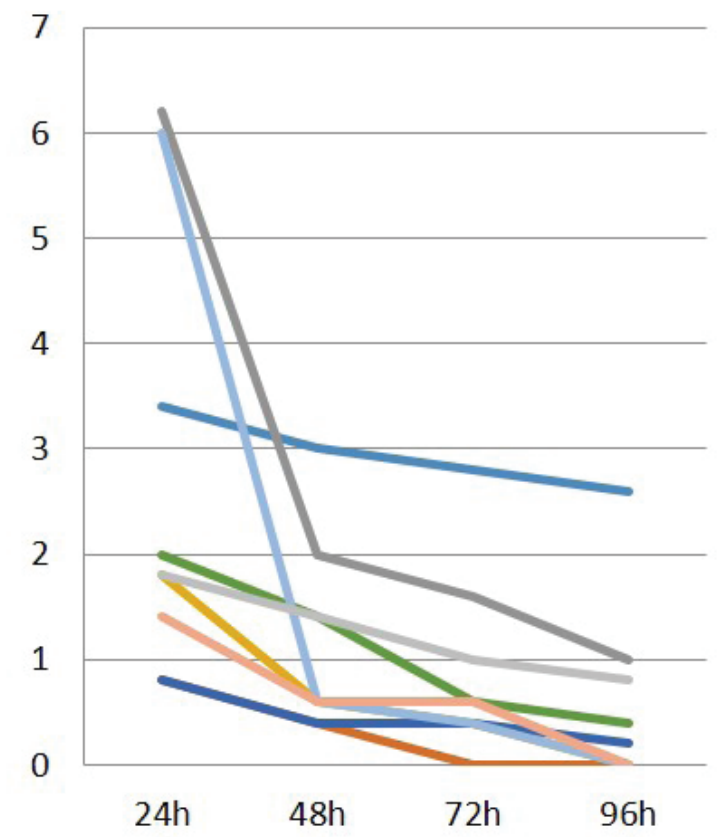

HGF Ki67 Non-biotinylated II

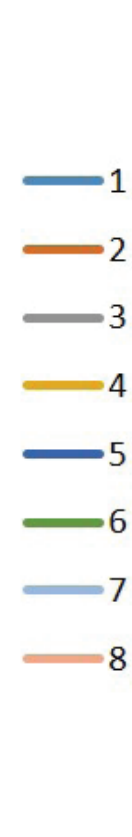

90
75
60
45
30
15
0

15
0

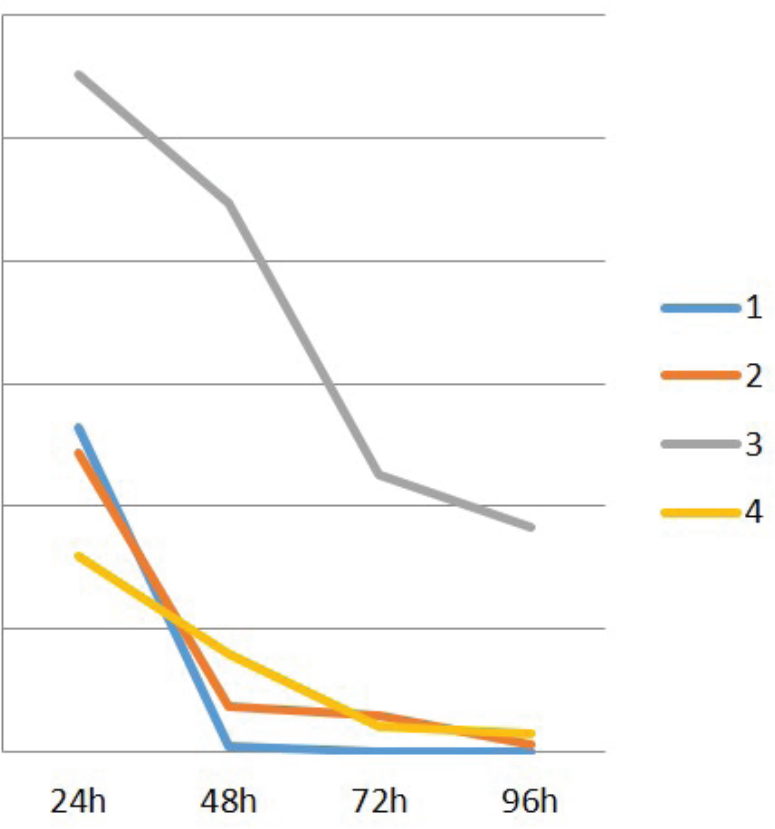

HGF Ki67 Biotinylated IV

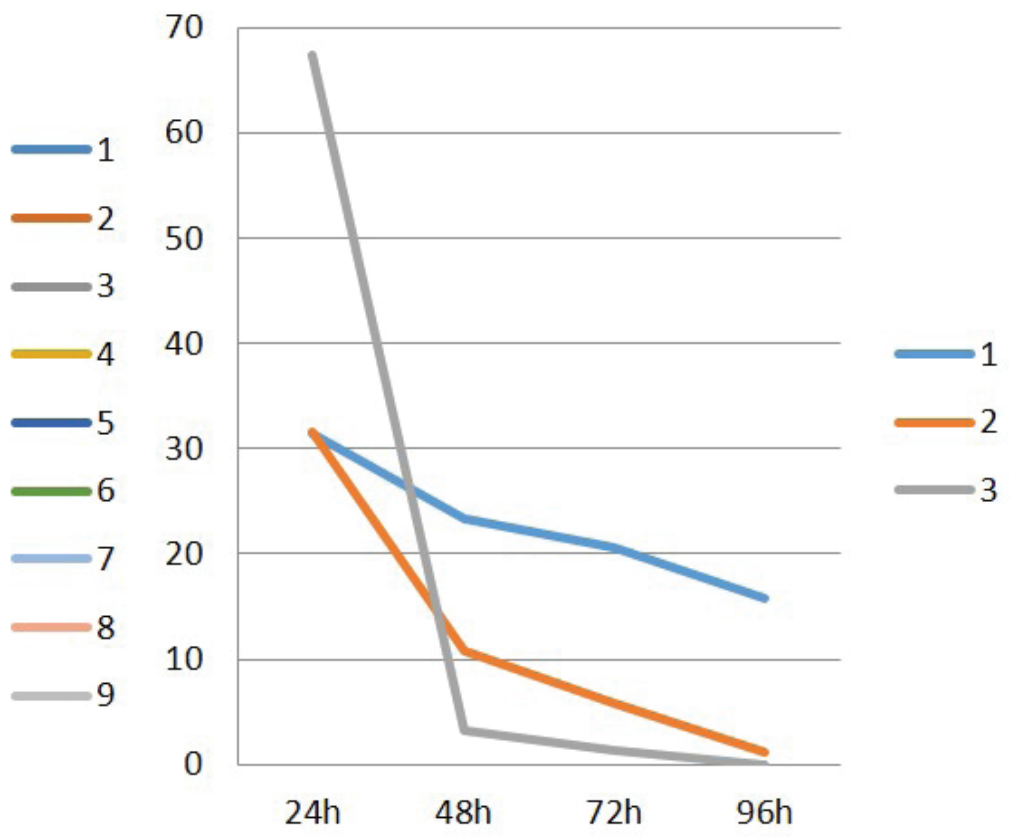

Fig.3. Absolute values for high (HGF) and low (LGF) cell growth fraction for Ki67 protein at the four formalin fixation times and in the two (non-biotinylated and biotinylated) amplification systems in the prospective study.

c-KIT gene are known to occur in biologically more aggressive neoplasms, but changes in the location of KIT immunostaining occur in all grades (Kiupel et al. 2004, Webster et al. 2006). As for pattern I immunostaining, it was observed mostly in cases classified as low grade by the KS, but also found in two high grade cases.
Failure in Ki67 antigen immunostaining, observed in $56 \%$ of the MCTs in the retrospective study, was possibly influenced by the prolonged formalin fixation time of some samples. A literature review conducted by Ramos-Vara \& Miller (2014) associated cumulative effects of formalin fixation and factors relative to tissue processing (exposure 
to alcohol and xylol) with failure to recognize Ki67 protein. That was the motivation for our prospective study, which sought to assess whether fixation time could be influencing the results of our retrospective study. Flores et al. (2016), using other samples from the same laboratory (LPV-UFSM), observed positive immunostaining for Ki67 protein in approximately $70 \%$ of the samples analyzed. The difference in the percentage of immunostaining between this study and that by Flores et al. (2016), even with different samples, could be associated with the systems of amplification (using a specific polymer for tissues of dogs and cats) and antigen retrieval (under controlled conditions of temperature and pressure) they used for Ki67 protein.

AgNOR is another method used to evaluate the cellular proliferation of a tumor. The AgNOR index could be used as an additional option for cases where IHC for Ki67 antigen could not be used, or in combination with the Ki67 result, as it will be discussed later. This is justified by the fact that the retrospective studies that used the AgNOR technique, possibly without knowledge of sample fixation time, did not mention the influence of fixation time on the results obtained (Rech et al. 2004, Lima et al. 2005).

Aiming to optimize the IHC technique for Ki67 protein, two amplification systems and four formalin fixation times were used in the prospective study. The advantage of the non-biotinylated system over the biotinylated system lies in the fact that the first is particularly simpler, has the same or even higher sensitivity, and presents lower background reaction compared with the latter (Ramos-Vara \& Miller 2014). Galiza et al. (2014) found differences in specificity and sensitivity between different amplification systems in IHC for detection for aspergillosis and zygomycosis. For zygomycosis, the non-biotinylated method showed high sensitivity and specificity, whereas the biotinylated method presented high sensitivity and specificity for aspergillosis.

Although some advantages of the non-biotinylated system over the biotinylated system have been described (Ramos-Vara \& Miller 2014), the present study observed changes (reduction in the number of immunostained cells) in determination of the growth fraction in the MCTs at fixation time of $48 \mathrm{~h}$ in both systems. This information is important at the same time that it raises concern, because it represents the reality of most veterinary pathology laboratories, which receive material with unknown formalin fixation times. The impaired detection of cells that would be immunostained under ideal fixation conditions (up to 24 hours) may result in determination of a low $(<23)$ instead of a high $(>23)$ growth fraction, entailing a mistaken prognosis. This fact is important because dogs with MCTs with high growth fraction (HGF) presented lower survival (Webster et al. 2007).

It is worth highlighting that, in addition to the impaired detection in the growth fraction in the prospective study, there were no MCTs without immunostaining for Ki67 protein in the two amplification systems used, especially after 48 hours of fixation. Alves \& Roman (2005) reported decreased positive immunostaining to proliferating cell nuclear antigen (PCNA) in tonsil samples, using the biotinylated system, in cases with formalin fixation longer than 24 hours. Other authors have found values of $43 \%$ (Fonseca-Alves et al. 2015) and $23 \%$ (Kandefer-Gola et al. 2015) failure in immunostaining for Ki67 protein in MCTs, and did not explain the reasons for such failures. According to Munakata \& Hendricks (1993), the best results for Ki67 antigen were observed in tonsil samples after 4 hours of formalin fixation, with weak immunostaining in samples after 48 hours of fixation. Furthermore, it should be noted that the delay in exposing the sample to the tissue cross-linking fixative can significantly alter immunostaining with antibodies to cell proliferation rates (Ramos-Vara \& Miller 2014), and this factor also depends on the veterinarian who sends the sample (clinician/surgeon), often without interference from the histopathological diagnostic laboratory.

Among the methods available to assess cell proliferation within a tumor, mitotic counting, although estimative, is the most commonly used by diagnostic laboratories (Romansik et al. 2007). This method, which is performed on slides stained using the hematoxylin and eosin (HE) technique, is simple and fast, and composes the criteria for histologic grading of MCTs (Kiupel et al. 2011, Souza et al. 2018). According to Sledge et al. (2016), cell proliferation is best and fully evaluated with the use of multiple methods. By multiplying the results of the AgNOR and Ki67 techniques (AgNOR x Ki67), it is possible to obtain the best cell proliferation rates within a neoplasm, because it associates growth rate with the cell growth fraction, respectively (Sledge et al. 2016, Kiupel 2017). Dogs diagnosed with AgNOR x Ki67 index $>54$ died within 12 months, whereas dogs with index $<54$ survived for two years (Webster et al. 2007). Although the literature describes that the best results of cell proliferation are obtained in combination, this study revealed that the combination of these techniques in the laboratory routine can be complicated, because the values for Ki67 antigen varied between fixation times. Likewise, it was observed that cases with formalin fixation time longer than 72 hours did not present immunostaining for this protein.

Using histologic grading, immunostaining pattern for KIT protein, and markers of cell proliferation, it is possible to choose the best therapy to be used in dogs with this neoplasm (Sledge et al. 2016). These techniques are offered by many laboratories to owners who wish, in addition to the histopathological diagnosis, other prognostic factors that enable the establishment of appropriate treatment for each situation and patient (Kiupel 2017).

\section{CONCLUSIONS}

This study demonstrates the importance to implement new tools in the search of the biological behavior of this neoplasm, but points to some barriers to be overcome in laboratory routine.

Immunostaining for KIT protein was efficient both at known (prospective study) and unknown, and possibly quite variable (retrospective study), fixation times.

Immunostaining for Ki67 antigen was highly sensitive to longer fixation time.

No differences were observed in immunohistochemical detection for KIT and Ki67 proteins in the comparison between the two amplification systems employed.

Assessment of Ki67 protein in previously formalin fixed samples, without knowledge of fixation time, presents variable results.

Thus, the AgNOR technique can be used as an alternative to evaluate cell proliferation rate in cases with fixation time longer than 24 hours. 


\section{REFERENCES}

Alves M.T.S. \& Roman L.C.M. 2005. Estudo do efeito de distintos períodos de fixação em formalina e métodos de recuperação antigênica na técnica de imuno-histoquímica. J. Bras. Patol. Med. Lab. 41(1):43-49. <http://dx.doi. org/10.1590/S1676-24442005000100010>

Bostock D.E. 1973. The prognosis following surgical removal of mastocytomas in dogs. J. Small Anim. Pract. 14(1):27-41. <http://dx.doi. org/10.1111/j.1748-5827.1973.tb06891.x> <PMid:4199921>

Bostock D.E., Crocker J., Harris K. \& Smith P. 1989. Nucleolar organiser regions as indicators of post-surgical prognosis in canine spontaneous mast cell tumors. Brit. J. Cancer 59(6):915-918. <http://dx.doi.org/10.1038/ bjc.1989.193><PMid:2500145>

Derenzini M. 2000. The AgNORs. Micron, Oxford, 31(2):117-120. <http:// dx.doi.org/10.1016/S0968-4328(99)00067-0><PMid:10588056>

Flores M.M., Mazaro R.D., Langohr I.M., Roy A., Strother K. \& Fighera R.A. 2016. Ancillary techniques on the evaluation of canine cutaneous mast cell tumors from Brasil. Ciência Rural 46(10):1804-1810. <http://dx.doi. org/10.1590/0103-8478cr20160255>

Fonseca-Alves C.E., Bento D.D., Torres-Neto R., Werner J., Kitchell B. \& LauferAmorim R. 2015. Ki67/KIT Double immunohistochemical staining in cutaneous mast cell tumors from Boxer dogs. Res. Vet. Sci. 102:122-126. <http://dx.doi.org/10.1016/j.rvsc.2015.08.007> <PMid:26412531>

Galiza G.J.N., Tochetto C., Rosa F.B., Panziera W., Silva T.M., Caprioli R.A. \& Kommers G.D. 2014. Utilização de três métodos imuno-histoquímicos na detecção de aspergilose e zigomicose em animais. Pesq. Vet. Bras. 34(7):637-642. <http://dx.doi.org/10.1590/S0100-736X2014000700005>

Goldschmidt M.H. \& Hendrick M.J. 2002. Tumors of the skin and soft tissues, p.44-117. In: Meuten D.J. (Ed.), Tumors in Domestic Animals. 4th ed. Iowa State Press, Ames. <http://dx.doi.org/10.1002/9780470376928.ch2>.

Gross T.L., Ihrke P.J., Walder E.J. \& Affolter V.K. 2009. Doenças de Pele do Cão e do Gato: diagnóstico clínico e histopatológico. Roca, São Paulo, p.837-842.

Kandefer-Gola M., Madej J.A., Dzimira S., Nowak M., Janus I. \& Ciaputa R. 2015. Comparative analysis of markers of cell proliferation in canine mast cell tumors according to current classifications. Pol. J. Vet. Sci. 18(2):241147. <http://dx.doi.org/10.1515/pjvs-2015-0031><PMid:26172171>

Kiupel M. 2017. Mast cell tumors, p.176-202. In: Meuten D.J. (Ed.), Tumors in Domestic Animals. 5th ed. Iowa State Press, Ames.

Kiupel M., Webster J.D., Bailey K.L., Best S., DeLay J., Detrisac C.J., Fitzgerald S.D., Gamble D., Ginn P.E., Goldschmidt M.H., Hendrick M.J., Howerth E.W., Janovitz E.B., Langohr I., Lenz S.D., Lipscomb T.P., Miller M.A., Misdorp W., Moroff S., Mullaney T.P., Neyens I., O'Toole D., Ramos-Vara J., Scase T.J., Schulman F.Y., Sledge D., Smedley R.C., Smith K.W., Snyder P., Southorn E., Stedman N.L., Steficek B.A., Stromberg P.C., Valli V.E., Weisbrode S.E., Yager J., Heller J. \& Miller R. 2011. Proposal of a 2-tier histologic grading system for canine cutaneous mast cell tumors to more accurately predict biological behavior. Vet. Pathol. 48(1):147-155. <http://dx.doi. org/10.1177/0300985810386469> <PMid:21062911>

Kiupel M., Webster J.D., Kaneene J.B., Miller R. \& Yuzbasiyan-Gurkan V. 2004. The use of KIT and tryptase expression patterns as prognostic tools for canine cutaneous mast cell tumors. Vet. Pathol. 41(4):371-377. <http:// dx.doi.org/10.1354/vp.41-4-371> <PMid:15232137>

Lima F.O., Catarino R.M., Oshima C.T.F. \& Figueiredo M.T.A. 2005. Regiões organizadoras nucleares argirofílicas no sarcoma sinovial. J. Bras. Patol. Med. Lab. 41(5):347-352. <http://dx.doi.org/10.1590/S167624442005000500010>
Munakata S. \& Hendricks J.B. 1993. Effect of fixation time and microware oven heating time on retrieval of the Ki-67 antigen from paraffinembedded tissue. J. Histochem. Cytochem. 41(8):1241-1246. <http:// dx.doi.org/10.1177/41.8.8331288><PMid:8331288>

Northrup N.C., Howerth E.W., Harmon B.G., Brown C.A., Carmicheal K.P., Garcia A.P., Latimer K.S., Munday J.S., Rakich P.M., Richey L.J., Stedman N.L. \& Gieger T.L. 2005a. Variantion among pathologist in histologic grading of canine cutaneous mast cell tumors with uniform use of a single grading reference. J. Vet. Diagn. Invest. 17(6):561-564. <http://dx.doi. org/10.1177/104063870501700606><PMid:16475514>

Northrup N.C., Harmon B.G., Gieger T.L., Brown C.A., Carmichael K.P., Garcia A., Latimer K.S., Munday J.S., Rakich P.M., Richey L.J., Stedman N.L., Cheng A.L. \& Howerth E.W. 2005b. Variantion among pathologist in histologic grading of canine cutaneous mast cell tumors. J. Vet. Diagn. Invest. 17(3):245-248. <http://dx.doi.org/10.1177/104063870501700305><PMid:15945380>

Ozaki K., Yamagami T., Nomura K. \& Narama I. 2007. Prognostic significance of surgical margin, ki-67 and cyclin d1 protein expression in grade in canine cutaneous mast cell tumor. J. Vet. Med. Sci. 69(11):1117-1121. <http:// dx.doi.org/10.1292/jvms.69.1117><PMid:18057825>

Patnaik A.K., Ehler W.J. \& Macewen E.G. 1984. Canine cutaneous mast cell tumor: morphologic grading and survival time in 83 dogs. Vet. Pathol. 21(5):469-474. <http://dx.doi.org/10.1177/030098588402100503> <PMid:6435301>

Ramos-Vara J.A. \& Miller M.A. 2014. When tissue antigens and antibodies get along: revisiting the technical aspects of immunohistochemistry - the red, brown, and blue technique. Vet. Pathol. 51(1):42-87. <http://dx.doi. org/10.1177/0300985813505879> <PMid:24129895>

Rech R.R., Graça D.L., Kommers G.D., Sallis E.S.V., Raffi M.B. \& Garmatz S.L. 2004. Mastocitoma cutâneo canino: estudo de 45 casos. Arq. Bras. Med. Vet. Zootec. 56(4):441-448. <http://dx.doi.org/10.1590/S010209352004000400004>

Romansik E.M., Reilly C.M., Kass P.H., Moore P.F. \& London A. 2007. Mitotic index is predictive for survival for canine cutaneous mast cell tumors. Vet. Pathol. 44(3):335-341. <http://dx.doi.org/10.1354/vp.44-3-335> <PMid:17491075>

Sledge D.G., Webster J. \& Kiupel M. 2016. Canine cutaneous mast cell tumors: a combined clinical and pathologic approach to diagnosis, prognosis, and treatment selection. Vet. J. 215:43-54. <http://dx.doi.org/10.1016/j. tvjl.2016.06.003><PMid:27372911>

Souza A.C.F., Pascoli A.L., Ferreira M.G.P.A., Reis Filho N.P., Silva I.C.R., Santos R.R., Faro A.M. \& De Nardi A.B. 2018. Mastocitoma cutâneo canino: estudo retrospectivo dos casos atendidos pelo serviço de oncologia do Hospital Veterinário da FCAV-Unesp, Campus Jaboticabal, de 2005 a 2015. Pesq. Vet. Bras. 38(9):1808-1817.<http://dx.doi.org/10.1590/1678-5150-pvb-5150>

Strefezzi R.F., Kleeb S.R., Xavier J.G. \& Dias J.L.C. 2010. Avaliação da proliferação cellular como indicador prognóstico para mastocitomas cutâneos caninos. Pesq. Vet. Bras. 30(7):559-565. <http://dx.doi.org/10.1590/S0100736X2010000700009>

Webster J.D., Yuzbasiyan-Gurkan V., Miller R.A., Kaneene J.B. \& Kiupel M. 2007. Cellular proliferation in canine cutaneous mast cell tumors: associations with c-KIT and its role in prognostication. Vet. Pathol. 44(3):298-308. <http://dx.doi.org/10.1354/vp.44-3-298><PMid:17491070>

Webster J.D., Yuzbasiyan-Gurkan V., Kaneene J.B., Miller R.A., Resau J.H. \& Kiupel M. 2006. The role of c-KIT in tumorigenesis: evaluation in canine cutaneous mast cell tumors. Neoplasia 8(2):104-111. <http://dx.doi. org/10.1593/neo.05622><PMid:16611403> 